\title{
Corporate Governance in Bangladesh: Evidence of Compliance
}

\author{
Chowdhury Saima Ferdous ${ }^{1}$ \\ ${ }^{1} \mathrm{PhD}$, Associate Professor, Department of International Business, University of Dhaka, Bangladesh \\ Correspondence: Chowdhury Saima Ferdous, PhD, Associate Professor, Department of International Business, \\ University of Dhaka, Bangladesh.
}

Received: December 26, 2017

Accepted: February 5, 2018

Online Published: February 12, 2018

doi:10.5539/ibr.v11n3p88

URL: https://doi.org/10.5539/ibr.v11n3p88

\begin{abstract}
This study investigates companies' level of compliance with the Code of Corporate Governance for Bangladesh. Using a quantitative approach, it aims to understand the extent a regulatory provision can enhance the governance scenario of a company. It employed a survey methodology, with a questionnaire being sent to all 229 companies listed on the Dhaka Stock Exchange. The results of the multivariate analysis suggest that age, size, industry and type of company have a statistically positive correlation with the level of compliance with the Code provisions. The findings of the study indicate that listed companies are, on average, moderately compliant with the Code, and compliance is comparatively higher with the Code provisions that coincide with other regulatory provisions. The major theoretical contribution of this study is with its empirical evidence of the code compliance literature from a developing country perspective. Moreover the findings can be used as a guide to help develop policies for better implementation of good governance standards; the identification of areas of non-compliance are expected to help code formulators, regulators and also companies to understand why and where companies are falling behind in compliance with the Code.
\end{abstract}

Keywords: corporate governance, Bangladesh, developing countries, board of directors, financial reporting

\section{JEL Classification: G21}

\section{Introduction}

The case of Bangladesh as an emerging economy presents an interesting case to study. In one side, the economy of the country presents a prosperous scenario, whilst the other side raises question about its sustainability. For instance, over the last two and half decades, the economy of Bangladesh has made commendable progress. GDP growth rate in Bangladesh averaged 5.69 percent from 1994 until 2016, reaching an all time high of 7.11 percent in 2016. The government of the country has made strong commitment for meeting the economic target of reaching Middle Income Country (MIC) status in 2021 by ensuring an annual 8\% GDP growth. However, the other side of the reality of the country does not speak the same. Despite this robust growth rate the country has still remained as one of the poorest countries in the world (Sobhan 2016, Hasan et al., 2014, Ferdous 2012, Azmat \& Coghill, 2010; Salman 2009; Sarkar 2011). Whilst attaining MIC goal demands good governance in all spheres of the economy of the country, the number of corporate scandal is increasing over the years (e.g. Hallmark, Bismillah Group, Oriental Bank, Modern Food Ltd etc.) along with two major stock market failures (one in 1996, and the second in 2011).

However, this contrasting scenario is not unique for Bangladesh; rather many of the countries are experiencing the same which perhaps has given the momentum for developing codes and establishing good governance. A number of studies are already in place highlighting the importance of good development and measurement of the level of compliance. For instance, Fernández-Rodríguez et al., 2004, Igor et al. 2006) opined that have empirically proved that disclosure of compliance has a positive impact on the stock market, or improves performance (e.g. Ahmed, 2014; Bauwhede, 2009; Mallin \& Ow-Yong, 2012), and helps the country to remain abreast (e.g. Akkermans et al., 2007). Findings of non-compliance further allow countries to trace the gap between the standards and reality following an appropriate action for code improvement (e.g. MacNeil \& $\mathrm{Li}$, 2006; Parsa et al., 2007). The study of Claessens \& Yurtoglu, 2013 reported that understanding corporate governance practices against best practices is vital particularly for the developing countries, because it helps to improve the governance standard, which in turn benefits companies through greater access to financing, lower cost of capital, better performance and more favorable treatment of all stakeholders; and that is why it is 
fundamental for Bangladesh to ensure good governance standard if it has to attain its development goals. A very recent study Armstrong et al. (2015) examined a sample of firms between 2007 and 2011 and find that CEOs' risk-taking equity incentives exhibits a positive relationship with the average level (i.e., conditional mean) of tax avoidance. This result is analogous to the positive relationship between risk-taking equity incentives and earnings management reported by Armstrong et al. (2013). Taking the case of Jordan, Al-Qaisi (2013) reported that companies especially non-financial sector is Jordan faces low performance standard due to lack of governance standard.

Following the spirit, Bangladesh has also developed its first voluntary code of corporate governance in 2004, and the Security and Exchange Commission of Bangladesh introduced its first specific Corporate Governance Regulation for its listed companies in 20016 on a "comply-or-explain" basis (which has been revised in 2012 and made mandatory). However, it is yet to be found to what extent the Codes have been successful in ensuring better governance standard. Although a few studies have considered understanding the status of governance in Bangladesh against some other mandatory and regulatory provisions (for example Sobhan 2016, Ahmed \& Yusuf, 2005, Belal, 1999, 2001, 2002, Belal and Owen, 2007, Imam \& Malik, 2007, Siddiqui, 2010, Sobhani et al., 2009, Uddin \& Choudhury, 2008, Uddin \& Hopper, 2003), none has considered understanding the extent to which companies in Bangladesh reflect an international standard of governance by systematically measuring compliance against the voluntary Code of Corporate Governance for Bangladesh 2004 (the Code).

The present study aims to fill this gap in the literature. In particular, the study aims to identify the overall level of compliance of Bangladesh's listed companies with the Code of Corporate Governance for Bangladesh, including identifying whether some of the Code provisions are complied with more than others; and secondly to examine whether the compliance level varies depending on different company attributes.

The findings of this study are expected to have several theoretical and practical contributions. The findings of this study will add to the evidences on the level of compliance from an emerging nation. Secondly, every country is unique with its cultural and demographic features; hence evidences of compliance with standard code provisions will enlighten the existing knowledge on compliance behavior, which will help the policy makers to amend the code or corporate practices accordingly. Thirdly, the findings relating of non-compliance will help the practitioner in taking corrective action. Researchers like Minichilli et al. (2016) and Wanyama et al (2009) opined that the development of codes is the right starting point for reforming corporate practices, but in developing countries which are characterized by pervasive corruption, and a weak legal system, the mere development of a code will not guarantee that de facto, practice will improve; it needs change in the overall framework. A great deal of studies have also indicated that the development of codes should be followed by regular monitoring over compliance, reviewing their effectiveness and understanding the possible scope for their improvement (e.g. Armstrong \& Vashishtha, 2012; Aboagye \& Otieku, 2010; Campbell et al., 2009; Dartey-Baah \& Amponsah-Tawiah, 2011; Green et al., 2003; Ibrahim, 2006; Kota \& Tomar, 2010; Manosa et al., 2007; Ogbuozobe, 2009; Singh \& Newberry, 2008; Tsamenyi et al., 2007). There is a lack of research that investigates the challenges companies in Bangladesh are facing in ensuring full compliance, or investigating the solutions for ensuring full compliance. The findings of this research are thus expected to help the policy makers in revising the code provision and take corrective actions.

It is important to note that this study will measure compliance in terms of disclosure. The listed companies of Bangladesh will comprise the population of this study. As have been mentioned above that the SEC of Bangladesh has introduced its first corporate governance guidelines in 2006 on a 'comply or explain' basis and then it has been revised again in 2012 as a mandatory provision. The philosophy of good governance emphasizes on voluntary compliance more, whilst the evidence indicates that in absence of strong legal and regulatory system it will be hard for a country to ensure good governance on any basis other than the mandatory one. Hence, this study intends to measure the level of compliance based on the 'comply or explain' basis first, which will provide the ground for future study to compare if the level of compliance has improved after making it mandatory.

The remainder of the paper proceeds as follows. In section 2 we briefly discuss the compliance environment and the development of the Code of Corporate Governance for Bangladesh. Section 3 reviews the literature and develops the hypotheses whilst section 4 outlines the research design. The results are presented in section 5 , and finally section 6 summarizes the findings and concludes the paper.

\section{Review of the Compliance Environment and the Code of Corporate Governance for Bangladesh}

Researchers (Ferdous, et al., 2014, Arun \& Turner, 2004, La Porta et al., 1997, 1998, Mallin, 2010, Rossouw, 2005) have long argued that a country's legal system is strongly related to market efficiency. Indeed, the 
researchers on Bangladesh (see Belal, 2001, Belal \& Owen, 2007, Joy, 2005, Kha et al., 2009) have also emphasized the legal framework of the country indicating that the corporate governance system of Bangladesh is fundamentally based on its legal and judicial system.

Bangladesh is a common law country. The companies are governed by the Company Act 1994 which is based on the 1908 UK Companies Act. This Act governs the relationship between shareholders and a company, the audit system, transparency, disclosure procedure and the jurisdiction of the courts in relation to companies. In addition to the Company Act 1994, there are also some other principle laws which shape the corporate governance system of Bangladesh: for example, the, Securities and Exchange Ordinance (1969) deals with investors' protection, capital issues, registration and regulation of the stock exchange, capital market regulation and issues in relation to securities.

At present there are four key regulatory institutions which influence Bangladeshi corporate governance from the viewpoint of establishing corporate governance norms and compliance. Firstly, the Registrar of Joint Stock Companies and Firms (RJSC) is responsible for registering companies under the Company Act 1994 and is administered by the Ministry of Commerce. Secondly, the Bangladesh Bank is the primary regulator of Banking and Non-Banking Financial Institutions in Bangladesh. Thirdly, the Securities and Exchange Commission (SEC) which was established in 1993 under the Securities and Exchange Commission Act 1993 and is in charge of regulating the capital market. The major purposes of the SEC are to provide protection of the interests of investors in securities, the development of the securities market and connected matters.

The companies are governed by the Company Act 1994 which is based on the 1908 UK Companies Act. All domestic companies of Bangladesh are incorporated under this Act. It governs the relationship between shareholders and a company, audit system, transparency, disclosure procedure and the jurisdiction of the courts in relation to companies (BEI, 2004).Following the political turmoil in 2013, law and order is restored, helping to facilitate business and economic growth. The Rana Plaza tragedy forced the government to introduce certain compliance requirements in the garments sector by enacting the Labour (Amendment) Act 2013. A new Companies Act is being finalized to replace the Companies Act 1994. The draft proposes certain treatments in line with the Organization for Economic Co-operation and Development (OECD) compliance framework.

In addition, there are some other principle laws influencing the corporate governance system of Bangladesh. For instance, the Securities and Exchange Ordinance 1969 deals with investors' protection, capital issues, registration and regulation of the Stock Exchange, capital market regulation and issues in relation to securities; the Securities and Exchange Commission Act 1993 provides for the establishment of the Securities and Exchange Commission; the Bangladesh Bank Order 1972 for regulating the Central Bank of Bangladesh; the Financial Institutions Act 1993 that establishes the provisions for $\mathrm{NBFI}^{1}$; Income Tax Ordinance 1984 contains provision for disclosure, audit, penalties for contravention of fiscal and revenue, matters; Bankruptcy Act 1997 deals with the insolvency issues; Factories Act 1965, Industrial Relations Ordinance 1969, Employment of Labor (Standing Orders) Act 1965 etc. deals with the social welfare of employees. A study on the judicial system of Bangladesh (Panday, 2011) reports that the country has well-organized court system which is the replica of the system introduced by British rulers. However, finding the influence of the executive branch of Government over the judiciary, the paper concluded with questioning the independence of the judiciary system of the country.

The Government of Bangladesh established the Board of Investment (BOI) in 1989 for accelerating private investment in Bangladesh. BOI is headed by the Prime Minister of the country and represented by the Ministers and Secretariats of the concerned ministries. However, the studies indicate that the functions of the BOI, laid down in the Investment Board Act, 1989, have totally lost their relevance and the definition of foreign investment enshrined in the Investment Act is outdated. Besides, a host of details needs to be re-adjusted to meet the present needs. Likewise, the Bangladesh Export Processing Zones Authority Act, 1980 needs to be looked into to put it in total accord with the Industrial Policy as well as the demands of the present situation.

Private sector investment in Bangladesh is prohibited for certain sectors including: arms and ammunition, defense equipment, forest plantation, mining and so on. However there is no there is no restriction in general on

\footnotetext{
"Financial Institution" means such non-banking financial institutions, which- i) Provide loans and advances for industries, commerce, agriculture or building construction; ii) Carry out the business of underwriting, receiving, investing and reinvesting shares, stocks, bonds, debentures issued by the Government or any statutory organization or stocks or securities or other marketable securities; or iii) Carry out installment transactions including the lease of machinery and equipment; or iv) Finance venture capital; and shall include merchant banks, investment companies, mutual associations, mutual companies, leasing companies or building societies.
} 
foreign investment except in sectors controlled by administrative licensing processes. Doing Business in Bangladesh, a private online based platform reports that foreign investor rights are protected under the Foreign Private Investment (Promotion and Protection) Act 1980.The Bangladesh Bank has outlined relevant procedures and formalities for all inward and outward remittance in its Guidelines for Foreign Exchange Transactions (GFET).Any transaction that has not been outlined in the GFET must obtain approval from the Bangladesh Bank.

There are several major incentives available to investors in Bangladesh. These includes, tax holidays, accelerated depreciation, concessionary duty on imported capital machinery, Incentives to export oriented industries and so on (Doing Business in Bangladesh) Some major acts relating FDI are Foreign Private Investment (Promotion and Protection) Act, 1980 (Annex III) and the Investment Board Act, 1989 (Annex IV). However, as the Chamber of Commerce of Bangladesh reports, although the investment policy has been changing from time to time whereas the relevant Acts, which are supposedly the means for enforcement of this policy, have remained static. Thus, while the Industrial Policy is being updated from time to time to respond to changing needs, the Acts, lacks enforcement mechanisms.

With the support of the World Bank and the International Monetary Fund (IMF), a private think tank, the Bangladesh Enterprise Institute (BEI), developed the voluntary Code, namely the Code of Corporate Governance for Bangladesh in 2004. BEI developed a Taskforce Committee for the Code development Later in 2006, the SEC of Bangladesh also introduced Corporate Governance Guidelines on a 'comply or explain' basis for its listed companies. However, the present study will be based on the voluntary code for Bangladesh as this was the "first mover" in corporate governance in Bangladesh, it is more comprehensive than the SEC's Corporate Governance Guidelines (The World Bank, 2009) and has been recognized as an international standard of governance for Bangladesh by different international bodies like the World Bank, the International Monetary Fund (IMF), and GCGF. Also this Code is the only one which is included for Bangladesh in the list of corporate governance codes issued by the European Corporate Governance Institute.

The Code is organized into three major parts: board issues; shareholder related issues; and issues related to financial reporting, auditing and non-financial disclosures. The Code also has some other sector specific provisions for state owned enterprises, NGOs and financial institutions. However, the present study is limited to the general provisions of the Code, and does not cover sector specific provisions. The board related provisions of the Code cover a wide area from the board's composition to developing different board committees. It also covers provisions related to the board agenda, directors' training, remuneration and evaluation of board performance. Whilst the shareholder related provisions include those that require companies to go beyond the legal requirements to further empower their shareholders, for instance, the proxy voting system for shareholders is a legal requirement in Bangladesh, but the Code also requires companies to allow shareholders to nominate the audit firms, to allow them to ask questions of the board to clarify issues and so on. The financial reporting, auditing and non-financial disclosure related provisions cover issues related to accounting standards, the internal and external audit system, financial and non-financial disclosure issues.

\section{Compliance with Codes: Review of Literature on Developed and Developing Countries and Hypothesis Formulation}

Over the last three decades the literature on code compliance has increased both in developed and developing countries (for example Alabdullah et al. 2016, 2014; Conyon et al., 2002; Garay \& González, 2008, Gompers et al., 2003, Hossain., 2008, Klapper \& Love, 2004, Mutawaa \& Hewaidy, 2010, Myring \& Shortridge, 2010, Parsa et al., 2007, Silveira and Saito, 2009). However, the studies measuring compliance are predominantly based on developed countries' code. Interestingly, most of these studies reflect optimistic findings (e.g. Akkermans et al., 2007; Brenman and McCafferty, 1997; Conyon and Mallin, 1997; Dahya et al., 2002; Pass, 2006; Werder et al., 2005). For instance, Conyon and Mallin (1997) is one of the pioneering studies which investigated the extent UK listed companies implemented the recommendations of the Cadbury Code of Best Practices. The study confirms that there has been a very high level of compliance with the Code. Some latter studies (e.g. Dedman, 2002; Weir \& Laing, 2000) also claimed the same i.e. the Cadbury Code is well accepted by the sample companies. A more recent study on companies on the UK's Alternative Investment Market (AIM) (Mallin \& Ow-Yong, 2012) examined the relationship between the level of compliance with Quoted Companies Alliance (QCA) corporate governance recommendations and the company, and ownership characteristics. The study found clear evidence that compliance in sample companies increases with company size, board size, the proportion of independent NEDs, the presence of turnover revenue, and being formerly listed on the Main Market.

The German and Dutch Code also seems to have received a high level of acceptance. For instance, Werder et al., 
(2005) investigated the overall acceptance of the German Code based on the compliance declaration of 408 firms listed at the Frankfurt Stock Exchange and reports that there is a high degree of acceptance of the Code which has potential to increase over time. Some other studies on the German Code (Drobetz et al., 2004; Rosen, 2007) also support such a claim and inspired companies for adherence. Bebenroth (2005) and Akkerman et al., (2007) examined the Dutch Code; Brenman \& McCafferty (1997) on the Irish Code; Del Brio et al.(2006) and Fernández-Rodríguez (2004) the Spanish Code - and the findings of these studies show a high degree of compliance, albeit at different level.

Consistent with the higher degree of compliance, developed countries code seems to yield positive impact on firm performance too. For instance, the most prominent example could be La Porta et al. (1999) who analyzed the differences in governance standards in 27 countries and claim that firms with better governance standard tend to have higher valuation. Gompers et al. (2003) is another popular study investigating the impact of compliance on firm value. They used 24 distinct provisions relating shareholders' rights for a sample of around 1500 firms per year from the US market during 1990s. The study constructed a 'Governance Index' to proxy for the shareholders rights and the data was derived from secondary sources. Compliance was measured in a straightforward way - by adding 1 point to each firm's score in case of compliance with every provision. This particular method of measuring compliance is found to be common across studies on code compliance.

The effectiveness of European countries' Codes has also been reported by some other studies. For instance, Fernández-Rodríguez et al. (2004), Del Brio et al. (2006) and Reverte (2009) have examined the impact of the Spanish Code; Igor et al. (2006) and Rosen (2007) for Germany; Alves \& Mendes (2004) for Portugal; whilst, the Cadbury Code has been studied by a number of studies (e.g. Apostolides, 2010; Dahya et al., 2002; Dedman, 2002; Doble, 1997; Mallin and Ow-Yong, 2010; Weir and Laing, 2000). These studies generally find a positive impact on firm performance upon compliance. The overall findings of this huge pool of research on developed countries indicate that, in general, the developed countries' companies are highly compliant with their codes.

By contrast in the case of developing countries, most of the studies indicated poor compliance, for example, analyzing the effect of corporate governance mechanisms on firm's financial performance for a sample consisting of 109 industrial and service companies in Jordan, Alabdullah et.al (2014) reported that board size has a negative association with firm financial performance. Furthermore, the empirical investigations also revealed that the presence of independent directors in the board is not associated with financial performance. Likewise, the result showed that CEO duality has no impact on firm financial performance. Tsamenyi et al.(2007), examining 22 listed companies on the Ghana Stock Exchange, find that the compliance in Ghana is generally low. More recently, Ogbuozobe (2009) and Olayiwola (2010) observed a significant divergence between corporate practices in Nigerian companies and the corporate governance recommendations. A number of other studies on developing countries including studies for Cyprus (Krambia-Kapardis and Psaros, 2006), Jordan (Alabdullah et. Al 2016, 2014; Al-Najjar, 2010), and Lebanon (Chahine and Safieddine, 2011) generally reported significant concerns with the extent of compliance by companies in their respective countries. Given that Bangladesh is a developing country, we therefore frame our first hypothesis as follows:

H1: The level of compliance of the Bangladeshi listed companies with the Code of Corporate Governance for Bangladesh ("the Code") will be low.

In terms of compliance in developing countries, the desire to try to ensure higher compliance has perhaps triggered an increasing number of studies on developing countries where scholars attempted to understand the compliance pattern, its influential factors and impact on performance (such as Akhtaruddin, 2005, Hossain, 2008, Mutawaa and Hewaidy, 2010, Owusu-Ansah, 1998, Wallace and Naser, 1995). In understanding the determinants of compliance earlier studies have explored different company attributes including company type, size, industry type, profitability, listing status, liquidity etc. Following the prior studies, our study further explores the association between six of these corporate characteristics and the level of compliance with the voluntary Code in Bangladesh. These characteristics are: company age, profitability, size, industry type, company type and type of auditor.

\subsection{Company Age}

Prior studies (such as Akhtaruddin, 2005, Mutawaa and Hewaidy, 2010, Owusu-Ansah, 1998) considered companies' age in years assuming that the extent of compliance may be influenced by a company's age. For instance, Owusu-Ansah (1998) presumed that older companies are comparatively in a better competitive position and thus may be more compliant than the younger companies, and empirically proved that company age has a statistically significant positive impact on mandatory disclosures in Hong-Kong and New Zealand. This leads us to the following hypothesis: 
H2: Company age is significantly associated with the extent of compliance with the Code provisions

\subsection{Profitability}

Profitability is one of the common factors among studies measuring the association between company characteristics and the level of compliance. However, the measurement of profitability varies across different studies. Among the most common ratios considered are: the return on assets (ROA), return on equity (ROE) and return on income (ROI). The findings of prior studies reveal a mixed scenario. While some report a positive correlation (i.e. Owusu-Ansah, 1998), others (Glaum and Street, 2003, Wallace et al., 1994) find no association. Furthermore some studies including Wallace and Naser (1995) add another dimension by finding a negative association between the two variables (profitability and level of compliance).

In the case of Bangladesh, the findings of Akhtaruddin (2005), in the context of mandatory disclosure, found that companies with higher profitability comply more than companies with lower profitability. However, from these three ratios, only the ROA data was available for all the sample companies; the present study therefore seeks to investigate whether the association remains the same in the case of voluntary provisions utilizing ROA as a measure of profitability. The following hypothesis is thus established:

H3: Company profitability as measured by ROA is positively associated with the extent of compliance with the Code provisions.

\subsection{Company Size}

Economic theory and a large amount of empirical evidence (e.g. Akkermans et al., 2007, Garay and González, 2008, Hossain., 2008, Klapper and Love, 2004, Krambia-Kapardis and Psaros, 2006, Lang and Lundholm, 1993, MacAulay et al., 2009, Mallin and Ow-Yong, 2012, Owusu-Ansah, 1998) suggest that company size is most likely to have a positive impact on the level of compliance.

Previous studies have measured company size using different measurements such as sales, total assets, number of employees, market capitalization. However the most common variable used was total assets (Al-Najjar, 2013). Hence the present study considered total assets to test the following hypothesis:

H4: Company size as measured by total assets of the company is positively associated with the level of compliance with the Code.

\subsection{Type of Industry}

The economic sector in which the company is operating may affect management interest toward better compliance (Mutawaa and Hewaidy, 2010, Wallace and Naser, 1995, Wallace et al., 1994). However, the findings of prior studies are inconclusive. While some report a significant association between compliance and type of industry (see Wallace and Naser, 1995, Wallace et al., 1994), others find no association (i.e. Glaum and Street, 2003, Owusu-Ansah, 1998). However, an understanding of the impact of industry type on compliance in the case of Bangladesh is important because some of the industrial sectors are highly exposed to the international market, and thus have been declared by the Government as a growth sector. These industrial sectors are expected to be more compliant than the other sectors. Hence the following hypothesis is derived:

H5: The type of industry is significantly associated with the extent of compliance with the Code provisions.

\subsection{Type of Company}

The extent of compliance may also be influenced by the origin and control of a company. Especially for developing countries like Bangladesh, where corporate governance is still at an early stage, it is expected that the companies which are domestically owned and controlled will comply differently with international standards of governance than the companies which are controlled by foreign companies (MNCs) or other types of company (e.g. joint ventures (JV) or franchise companies) where the parent company has a certain level of influence over the company management. Hence the variable "type of company", is divided into three groups - 'Local', 'MNC' and 'JVs and Franchise' and we hypothesize that:

H6: The type of company is significantly associated with the extent of compliance with the Code provisions.

\subsection{Type of Auditors}

Bangladesh has four large audit firms who are affiliated with the international Big4 audit firms. Since prior studies (like Glaum and Street, 2003, Mutawaa and Hewaidy, 2010, Street and Gray, 2002) found that there is a positive association between the type of auditor and the level of compliance, this study has also investigated 
whether the type of auditor significantly influences the level of compliance with the Code.

H7: The type of auditor (Big4 affiliate) is significantly associated with the extent of compliance with the Code provisions.

\section{Data and Methodology}

\subsection{Sample Selection and Data Collection}

The target population of the study is the companies listed on the Dhaka Stock Exchange (DSE), the largest stock exchange in Bangladesh at the end of 2010. The year 2010 was chosen because it was the last year for which annual reports of the listed companies were filed and uploaded on the SEC website at the time of conducting the empirical work. During that period a total of 229 companies (including both Financial and Non-Financial Institutions) were listed on the DSE. A questionnaire was developed (see below) and sent to all 229 of these listed companies, with the request that the Company Secretary (if not Director or Chairman) should complete the questionnaire; 71 companies responded.

Table 1 detail the industry classes of the companies on the DSE and shows that $48 \%$ of the sample is from the listed Banking and Non-Banking Financial Institutions (FIs) and $52 \%$ is from the listed Non-Financial Institutions (NFIs) of the country.

Table 1. Industry Classes of Companies on the Dhaka Stock Exchange

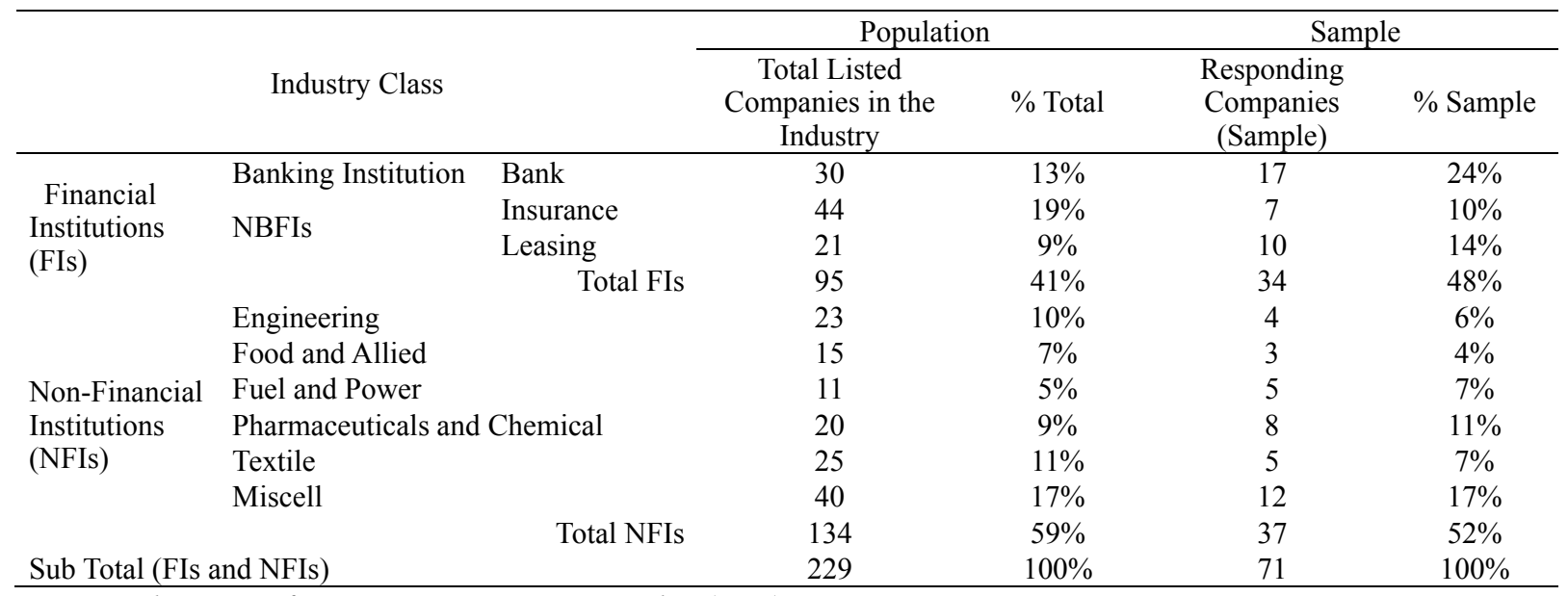

\subsection{Development of Corporate Governance Index (CGI)}

Most studies on code compliance (i.e. Akkermans et al., 2007, Garay and González, 2008, Klapper and Love, 2004, Leal and Carvalhal-da-Silva, 2005, Mutawaa and Hewaidy, 2010) have gathered information using a corporate governance index (CGI). In the same spirit, this study has also constructed its own CGI according to the Code of Corporate Governance for Bangladesh. Since the purpose of this study is to examine the extent to which companies in Bangladesh are complying with the provisions of the Code, every single provision of the Code was considered when constructing the index. Two separate indexes have been formulated for this study: one for the FIs and the other for the NFIs because the Code has some additional provisions for the FIs.

\subsection{Selection of Provisions for the CGI}

Some provisions of the Code are based on objective facts, such as having an audit committee, preparing the board agenda etc; whilst some others are more subjective. For instance one of the provisions asks companies to serve the legitimate interest of shareholders, whilst another one asks the credit assessment and loan approval process to be separated from personal conflict and political influence.

However, scholars like Klapper and Love (2004) and Owusu-Ansah (1998) argued that the problem with this kind of subjective provision is that research needs to depend on respondents' opinion as these are difficult for cross verification. They therefore excluded this type of subjective provision from their CGI. Hence, the present study concentrates only on the objective type of provisions which are based on objective facts and can be cross verified from companies other published documents (eg. via the annual reports).

\subsection{Designing Questionnaires and Scoring the CGI}

The questionnaires for the NFIs had 68 provisions in total divided into three sub-sections: board issues (39 questions); shareholders' rights (12 questions); and financial reporting (17 questions). The questionnaire for the 
FIs had 13 additional provisions, along with the earlier 68, which are included in the questionnaire for the NFI.

Both the questionnaires are designed with binary 'Yes'/'No' questions. Code provisions have been rephrased in most of the cases to convert them into questions while keeping the meaning of the provision intact. The purpose of rephrasing is to make the provisions easy for respondents to understand and also to facilitate analysis of the research.

Compliance is determined on the basis of the responses from the questionnaire. Although one may question whether responses of compliance do actually reflect compliance in practice, considering the sensitive nature of corporate governance research and considering the possibility of diagnosing compliance in real life, almost all of the previous studies have adopted disclosure as a measure of compliance. Following previous studies (for instance Cooke, 1989, Hossain, 2008, Mallin and Ow-Yong, 2012, Wallace et al., 1994), a dichotomous procedure was adopted in which an item scores one if complied with and zero if not. This method is known as an unweighted approach for scoring the CGI. According to this method, each company's CGI is defined as:

$$
\begin{aligned}
& \mathrm{CGI}_{\mathrm{y}}=\sum \mathrm{C}_{\mathrm{iy}} \\
& \text { Where, } \\
& \mathrm{n}_{\mathrm{y}}=\text { number of provisions complied with by the } \mathrm{y}^{\text {th }} \text { company } \\
& \mathrm{C}_{\mathrm{iy}}=1 \text { if the } \mathrm{i}^{\text {th }} \text { provision of the Code is complied with; } 0 \text { otherwise }
\end{aligned}
$$

In line with the framework analysis used by other scholars (for example, Mutawaa and Hewaidy, 2010, Samaha and Stapleton, 2008) a distinction is made between four levels of company compliance with the Code provisions. Companies are considered to be highly compliant if the compliance score is $80 \%$ or more, to have intermediate compliance between $79 \%$ and $60 \%$, low compliance between $59 \%$ and $40 \%$ and below $40 \%$ reflects a substantial gap between company compliance with the particular provisions and what might be expected.

\subsection{Model Development}

The study selected independent variables based on the hypotheses that were developed earlier. These variables are: company age, profitability, size, industry type, company type, and the type of external auditors used in companies. These variables were examined with the dependent variable (CGI) of each sample company to evaluate the extent to which the CGI varies across different company attributes.

The questionnaire survey and secondary sources (the 71 respondent companies' annual reports) elicited both numeric and categorical data. However, three variables are of a continuous nature (company age, profitability and size), and the other three independent variables (industry type, company type, and auditor type) are categorical with a domination of dichotomous or binary variable. Hence these variables were turned into quantitative variables by taking one of the categories as a baseline (against which all other categories are compared) and defining a dummy variable for the other categories.

The following Ordinary Least Square (OLS) regression model was fitted to the data in order to assess the effect of each variable on the level of compliance:

$$
\begin{aligned}
& \mathrm{CGI}_{\mathrm{y}}=\beta 0+\beta 1 \log \_ \text {age }+\beta 2 \log \_ \text {roa }+\beta 2 \log \_ \text {size }+\beta 4 \text { ind_type }+\beta 5 \text { com_type }+\beta 6 \text { aud_type }+\mathrm{e} \\
& \text { Where, } \\
& \text { CGI is the corporate governance index representing the compliance score, } \\
& \beta 0=\text { the intercept; } \\
& \text { and the control variables are: } \\
& \text { log_age = logarithm of the age of the company; } \\
& \log _{-} \text {roa }=\text { profitability of the company measured by the logarithm of ROA (return on } \\
& \text { assets); }
\end{aligned}
$$

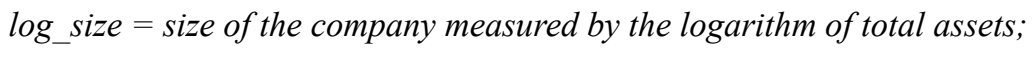

$$
\begin{aligned}
& \text { ind_type = type of industry; }
\end{aligned}
$$




$$
\begin{aligned}
& \text { com_type = type of company; } \\
& \text { aud_type }=\text { type of auditor used by the company; } \\
& e=\text { random or stochastic error term. }
\end{aligned}
$$

\section{Results}

\subsection{Level of Compliance of the Sample Companies}

Table 2 presents the descriptive statistics of the compliance score of the sample companies. The mean value is 67.14 (median $=69$ ), indicating that on average the sample companies are complying with $67 \%$ of the Code provisions. In accordance with the compliance framework outlined earlier, the sample companies have an intermediate level of compliance with the Code.

Table 2. Descriptive Statistics of the Percentage of the CGI of the Sample Companies

\begin{tabular}{|c|r|r|c|c|c|r|r|r|}
\hline & \multicolumn{1}{|c|}{$\mathrm{N}$} & Range & Min & Max & Mean & Std. Deviation & Skew ness & Variance \\
\hline CGI & 71 & 40.00 & 44.00 & 84.00 & 67.1408 & 9.16561 & -.509 & 84.008 \\
\hline
\end{tabular}

Table 2 also shows that the standard deviation is 9.17 ; indicating that the compliance score/corporate governance index (CGI) of some firms are not close to the average governance index. The range 40 in Table 2 implies that the distribution is likely to have resulted from a widespread difference in the quality of governance (e.g. maximum score is 84 , whilst the minimum is 44 ) among the sample companies.

Given the results presented in Table 2 some interesting facts emerge about the status of compliance among the sample companies. The majority of the companies' CGI (73\%) is within the range of $79 \%$ to $60 \%$ indicating that the majority of the sample companies are complying with the Code at an intermediate level. However $21 \%$ of the companies are poorly compliant with the Code as their compliance score ranges from $59 \%$ to $40 \%$; whilst $6 \%$ of the sample companies are highly compliant with the Code, as indicated by their level of compliance $(80 \%$ and above). Overall, for $94 \%$ of the sample companies in all industrial sectors, there was found to be a $50 \%$ compliance level. Therefore, this suggests that the majority of the listed companies are at least complying with half of the Code provisions.

Moreover, none of the companies have been reported as having a zero level of compliance, therefore none of the companies can be categorized as being absolutely non-compliant; whilst equally none can claim to be fully compliant with the Code provisions. All these findings re-emphasize that the Bangladeshi listed companies moderately comply with the voluntary Code.

Therefore referring to $\mathrm{H} 1$ that the level of compliance of the Bangladeshi listed companies with the Code will be low, the findings do not tend to support this hypothesis as we find higher levels of compliance than in some other developing countries. As mentioned above, the average level of compliance is $67 \%$ indicating that the majority of the sample companies are complying with the Code at an intermediate level. We therefore carried out further analysis to determine whether some of the Code provisions are adhered to more than others, and what might be driving this higher level of compliance with some of the Code provisions.

\subsection{Compliance Levels with Different Areas of the Code}

Table 3 suggests that among the three sub-indices of the Code (the board, shareholder, and financial reporting issues) the sample companies are mostly compliant with the financial reporting issues, whilst being comparatively less compliant with board related issues.

\begin{tabular}{|c|c|c|c|c|c|c|}
\hline & & $\mathrm{N}$ & Mean & Min & Max & Std. Dev \\
\hline CGI on Board Issues (Total 34 Provisions) & & 71 & 20.88 & 13 & 31 & 3.87 \\
\hline & & $\mathrm{N}$ & Mean & Min & Max & Std. Dev \\
\hline Percentage of Compliance Score with Shareholder Issues & & 71 & 63.61 & 33.33 & 83.33 & 11.97214 \\
\hline Provisions Relating Financial Reporting, Auditing and & Non & $\begin{array}{l}N \\
71\end{array}$ & $\begin{array}{c}\text { Mean } \\
75.5442\end{array}$ & $\begin{array}{c}\text { Min } \\
36.36\end{array}$ & $\begin{array}{c}\text { Max } \\
90.91\end{array}$ & $\begin{array}{c}\text { Std. Dev } \\
12.72\end{array}$ \\
\hline
\end{tabular}

Table 3. Status of the CGI, related to Three Sub-Indices (Board Provisions, Shareholder \& Financial Reporting Issues) by Sample Companies

Financial Disclosure

Comparatively high compliance with the financial reporting issues is not actually surprising because some recent studies on the audit and accounting system of Bangladesh (Siddiqui 2011, Siddiqui \& Podder, 2002, Uddin \& 
Choudhury, 2008) indicated that despite the limitations and inadequacies the recent changes of the ICAB might impact on the audit and accounting system of Bangladesh. Nonetheless, less compliance with the board related provisions may be related issues to do with the family-dominant corporate sector, the lack of infrastructure and the lack of concern about the necessity of ensuring good governance. Whilst it seems clear that unless people understand the value of compliance, the board of directors, who are mostly comprised of family members, will not welcome provisions related to performance evaluation or disclosure of their achievements, it is also the case that even if a company realizes the value of compliance there is no training institute which can afford to train them regularly. In this case the companies cannot be blamed for non-compliance; rather the Code provision should consider conditions in the country's existing infrastructure and how these might evolve in the future.

Interestingly the question arises that if there is increasing pressure and regulatory provisions are also being made on the reporting issues, then why did this area of the Code at least not achieve high compliance? Yet the findings in Table 3 indicate that in all the three sub-indices, consistent with the overall status of compliance, the sample companies are on average moderately compliant with the Code. Hence the study attempted to have a better insight into the provisions by identifying the provisions which had below $50 \%$ and above $80 \%$ compliance.

Table 4. List of the Least Complied (with CGI below 0.50) Provisions of the Code

\begin{tabular}{|c|c|c|c|c|}
\hline & \multirow{2}{*}{$\begin{array}{l}\text { Provisions of the Code of Corporate Governance for } \\
\text { Bangladesh }\end{array}$} & \multirow{2}{*}{$\begin{array}{l}\text { Mean } \\
\text { CGI }\end{array}$} & \multicolumn{2}{|c|}{$\begin{array}{l}\text { Does the Code provision } \\
\text { coincide with the following } \\
\text { three CG regulations? }\end{array}$} \\
\hline & & & $\begin{array}{c}\text { SEC } \\
\text { Guidelines }\end{array}$ & \begin{tabular}{|c|c|} 
Company Act \\
1994
\end{tabular} \\
\hline & \multicolumn{4}{|l|}{ Board Issues: Duties of the Board } \\
\hline 1 & $\begin{array}{l}\text { Does the board collectively participate in the appointment of } \\
\text { senior management? }\end{array}$ & 0.11 & $\mathrm{x}$ & $\mathrm{x}$ \\
\hline 2 & $\begin{array}{l}\text { Does the Board evaluate the performance of its individual } \\
\text { members? }\end{array}$ & 0.10 & $\mathrm{x}$ & $\mathrm{X}$ \\
\hline \multirow[t]{2}{*}{3} & $\begin{array}{l}\text { Does the Board have in place a succession plan for senior } \\
\text { management and the MD/CEO? }\end{array}$ & 0.34 & $\mathrm{x}$ & $\mathrm{x}$ \\
\hline & \multicolumn{3}{|l|}{ Board Issues: Board Membership Criteria } & \\
\hline 4 & $\begin{array}{l}\text { Is the board free from directors holding directorship in more } \\
\text { than } 6 \text { boards? }\end{array}$ & 0.41 & $\mathrm{x}$ & $\mathrm{x}$ \\
\hline \multirow[t]{2}{*}{5} & $\begin{array}{l}\text { Does the board have Nomination Committee or a particular } \\
\text { method to nominate qualified person for directorship? }\end{array}$ & 0.20 & $\mathrm{x}$ & $\mathrm{x}$ \\
\hline & \multicolumn{3}{|l|}{ Board Issues: Training of Board Members } & \\
\hline 6 & $\begin{array}{l}\text { Does the Board provide opportunities for training of individual } \\
\text { directors? }\end{array}$ & 0.36 & $\mathrm{x}$ & $\mathrm{x}$ \\
\hline 7 & $\begin{array}{l}\text { Does the Board provide funds for training of individual } \\
\text { directors? }\end{array}$ & 0.21 & $\mathrm{x}$ & $\mathrm{x}$ \\
\hline \multirow[t]{2}{*}{8} & $\begin{array}{l}\text { Does the Board require new directors to attend corporate } \\
\text { governance orientation or training program offered by reputed } \\
\text { institutions/individuals }\end{array}$ & 0.09 & $\mathrm{x}$ & $\mathrm{x}$ \\
\hline & \multicolumn{3}{|l|}{ Board Issues: Board Agenda } & \\
\hline \multirow[t]{2}{*}{9} & Is the Board Agenda approved solely by the Chairman? & 0.28 & $\mathrm{X}$ & $\mathrm{X}$ \\
\hline & \multicolumn{3}{|l|}{ Shareholders' Issues } & \\
\hline 10 & $\begin{array}{l}\text { Does your company provide a Shareholders Handbook which } \\
\text { informs shareholders about their rights and responsibilities? }\end{array}$ & 0.02 & $\mathrm{x}$ & $\mathrm{x}$ \\
\hline 11 & $\begin{array}{l}\text { Do the shareholders have an opportunity to nominate items for } \\
\text { the AGM agenda prior to the AGM meeting? }\end{array}$ & 0.28 & $\mathrm{x}$ & $\mathrm{x}$ \\
\hline 12 & $\begin{array}{l}\text { Can your shareholders nominate audit firms prior to the notice } \\
\text { of AGM? }\end{array}$ & 0.38 & $\mathrm{x}$ & $\mathrm{X}$ \\
\hline \multirow[t]{2}{*}{13} & Is the Handbook available and accessible to shareholders? & 0 & $\mathrm{X}$ & $\mathrm{X}$ \\
\hline & \multicolumn{3}{|l|}{ Financial Reporting: External Auditors } & \\
\hline \multirow[t]{2}{*}{14} & $\begin{array}{l}\text { Does a shareholder, nominating an audit firm need to submit } \\
\text { standardized information about the firm to facilitate } \\
\text { comparison among nominating firms? }\end{array}$ & 0.13 & $\mathrm{x}$ & $\mathrm{x}$ \\
\hline & \multicolumn{3}{|l|}{ Financial Reporting: Internal Auditors } & \\
\hline 15 & $\begin{array}{l}\text { Does your internal audit department have authority to propose } \\
\text { initiatives and changes directly to the board? }\end{array}$ & 0.46 & $\mathrm{x}$ & $\mathrm{x}$ \\
\hline \multirow[t]{2}{*}{16} & $\begin{array}{l}\text { Does their statements further signed by the Chairman of the } \\
\text { Audit Committee? }\end{array}$ & 0.10 & $\mathrm{x}$ & $\mathrm{x}$ \\
\hline & \multicolumn{3}{|l|}{ Financial Reporting: Disclosure } & \\
\hline 17 & $\begin{array}{l}\text { Does the company publicly disclose: Report on end use of } \\
\text { funds raised from public when using shares and debentures }\end{array}$ & 0.01 & $\mathrm{x}$ & $\mathrm{x}$ \\
\hline 18 & Does the company publicly disclose: Credit Rating & 0.49 & $\mathrm{X}$ & $\mathrm{X}$ \\
\hline
\end{tabular}


Table 4 includes the 18 provisions of the Code which have below $50 \%$ compliance. Among these 18 predominantly non-compliant areas, $50 \%$ belong to the board related issues, whereas only $22 \%$ and $28 \%$ of the provisions belong to the shareholder and financial reporting related provisions respectively. In the case of board related provisions, the sample companies are mostly non-compliant with the appointment of senior managers, or evaluation of board members' performance, training of board members etc. Whilst the lack of training institutes and infrastructure could be a plausible reason for non-compliance with training related issues, the Company Act 1994 was also found to be in need of revision as it was found to be silent in defining the independent directors, senior management etc. Thus, inadequate guidelines might also be a reason behind non-compliance with these kinds of provisions.

Although it has been argued that shareholders' rights are generally protected by laws in Bangladesh, Table 4 indicates that the provisions that aim to empower shareholders going beyond their legal rights, remained areas where companies tended to be non-compliant. In the case of financial reporting related provisions companies are non-compliant when the Code requires them to allow more power to internal auditors or to disclose information about the credit ratings and so on.

However, the last two columns of Table 4 indicate an interesting fact about the compliance attitude of the sample companies. It indicates that none of these 18 provisions coincides with the provisions in the SEC Corporate Governance Guidelines or the Company Act 1994 requirements; whereas Table 5 which includes the Code provisions which have received high compliance ( $80 \%$ and above) indicates that these provisions coincide with either one or both of these two regulatory requirements. This suggests that the companies' decision to comply with a particular provision is most likely to be influenced by the legal or regulatory institutions. This finding is consistent with Chen and Al-Najjar (2012) who found that, in the context of corporate governance reform in China, board independence is mainly driven by regulation

Table 5. List of the Most Complied (CGI 0.80 and above) Provisions of the Code

\begin{tabular}{|c|c|c|c|c|}
\hline & \multirow[t]{2}{*}{ Provisions of The Code } & \multirow{2}{*}{$\begin{array}{c}\text { Mean } \\
\text { CGI }\end{array}$} & \multicolumn{2}{|c|}{$\begin{array}{c}\text { Does the Code provision } \\
\text { coincide with the following two } \\
\text { CG regulations? }\end{array}$} \\
\hline & & & SEC Guidelines & $\begin{array}{l}\text { Company Act } \\
1994\end{array}$ \\
\hline & \multicolumn{3}{|l|}{ Duties of the Board } & \\
\hline 1 & Does a Code of Conduct exist for the board detailing directors' roles and responsibilities? & 0.89 & No & Yes \\
\hline 2 & Are the key risk areas of the company identified and monitored by the Board? & 0.94 & No & Yes \\
\hline 3 & Are the performance indicators of the company identified and monitored by the Board? & 0.99 & No & Yes \\
\hline 4 & $\begin{array}{l}\text { Does the Board collectively appoint the Managing Director (MD)/Chief Executive Officer } \\
\text { (CEO) }\end{array}$ & 0.90 & No & Yes \\
\hline \multirow[t]{2}{*}{5} & Is the internal control mechanism regularly reviewed and monitored by the Board? & 0.87 & Yes & No \\
\hline & \multicolumn{3}{|l|}{ Board Composition } & \\
\hline 6 & Is it mandatory to retire $20 \%$ of the board members annually by rotation? & 1.00 & No & Yes \\
\hline \multirow[t]{2}{*}{7} & Is the chairman of the board and CEO different persons? & 0.95 & Yes & No \\
\hline & \multicolumn{3}{|l|}{ Board Agenda } & \\
\hline \multirow[t]{2}{*}{8} & $\begin{array}{l}\text { Is the agenda for each board meeting circulated to directors sufficiently in advance of that } \\
\text { meeting? }\end{array}$ & 0.92 & No & Yes \\
\hline & \multicolumn{3}{|l|}{ Board Audit Committee } & \\
\hline 9 & $\begin{array}{l}\text { Does the company has an Audit Committee: (if 'NO', then please directly go to question } \\
\text { number25) }\end{array}$ & 0.97 & Yes & No \\
\hline 10 & $\begin{array}{l}\text { Does the Audit Committee exclude/ restrict the Chairman of the Board from being a } \\
\text { member of the Committee? }\end{array}$ & 0.87 & No & No \\
\hline 11 & Does the Audit Committee meet at least quarterly? & 0.83 & No & No \\
\hline 12 & Does the Audit Committee prepare reports on all meetings for the board? & 0.83 & Yes & No \\
\hline 13 & Is the Audit Committee comprised of at least three members, appointed by the board? & 0.90 & Yes & No \\
\hline
\end{tabular}




\begin{tabular}{|c|c|c|c|c|}
\hline & \multirow[t]{2}{*}{ Provisions of the Code } & \multirow{2}{*}{$\begin{array}{c}\text { Mean } \\
\text { CGI }\end{array}$} & \multicolumn{2}{|c|}{$\begin{array}{c}\text { Does the Code provision } \\
\text { coincide with the following two } \\
\text { CG regulations? }\end{array}$} \\
\hline & & & SEC Guidelines & \begin{tabular}{|c|c|c|} 
Company Act \\
1994 \\
\end{tabular} \\
\hline & \multicolumn{3}{|l|}{ Other Provisions } & \\
\hline 14 & $\begin{array}{l}\text { Does the board prepare a Directors' Report containing information as per the provision XI } \\
\text { (B) of the Code? }\end{array}$ & 0.81 & Yes & No \\
\hline 15 & $\begin{array}{l}\text { Has the company appointed a company Secretary or other qualified Compliance Officer or } \\
\text { any other external advisor (other than the auditor, company lawyer or other advisor to the } \\
\text { board) }\end{array}$ & 0.98 & Yes & No \\
\hline & \multicolumn{3}{|l|}{ Provisions Related to Shareholders } & \\
\hline 16 & $\begin{array}{l}\text { Do your shareholders receive notice of the AGM, through a standard means of } \\
\text { communication at least } 21 \text { days before the meeting? }\end{array}$ & 0.87 & No & Yes \\
\hline 17 & Are the outcome and proceedings of general meetings recorded and verified? & 0.97 & No & Yes \\
\hline 18 & $\begin{array}{l}\text { Is the AGM held in a convenient location in the vicinity of the company's registered } \\
\text { office? }\end{array}$ & 0.93 & No & Yes \\
\hline 19 & Do all the shareholders have the same voting right of 1 vote per share? & 0.96 & No & Yes \\
\hline 20 & $\begin{array}{l}\text { During the AGM, can your shareholders question the Board, subject to reasonable } \\
\text { limitations? }\end{array}$ & 0.96 & No & Yes \\
\hline & \multicolumn{3}{|l|}{ Financial Reporting: Accounting Standards and Accounts } & \\
\hline 21 & $\begin{array}{l}\text { Does your company ensure that the accounting standards are implemented within the time } \\
\text { framegiven by ICAB? }\end{array}$ & 1.00 & Yes & No \\
\hline 22 & $\begin{array}{l}\text { Does your company employ appropriately qualified personnel to prepare financial } \\
\text { statements and accounts? }\end{array}$ & 1.00 & No & Yes \\
\hline & \multicolumn{3}{|l|}{ Financial Reporting: External Auditors } & \\
\hline 23 & Are your external auditors independent? & 1.00 & Yes & Yes \\
\hline 24 & Are your external auditors appointed by the shareholders? & 0.99 & No & Yes \\
\hline 25 & $\begin{array}{l}\text { Does your company disclose both audit and non-audit fees (where applicable) to the } \\
\text { shareholders? }\end{array}$ & 0.96 & No & Yes \\
\hline
\end{tabular}

\begin{tabular}{|c|c|c|c|c|}
\hline & \multirow{2}{*}{ Provisions of the Code } & \multirow{2}{*}{$\begin{array}{c}\text { Mean } \\
\text { CGI }\end{array}$} & \multicolumn{2}{|c|}{$\begin{array}{c}\text { Does the Code provision } \\
\text { coincide with the following two } \\
\text { CG regulations? }\end{array}$} \\
\hline & & & SEC Guidelines & $\begin{array}{l}\text { Company Act } \\
1994\end{array}$ \\
\hline & Financial Reporting: Internal Auditors & & & \\
\hline \multirow[t]{2}{*}{26} & Does your company have an internal audit function? & 1.00 & Yes & Yes \\
\hline & Financial Reporting: Disclosure & & & \\
\hline 27 & $\begin{array}{l}\text { Does your Board present a balanced assessment of the company's position that may be } \\
\text { understood by shareholders? }\end{array}$ & 1.00 & Yes & Yes \\
\hline 28 & Does the company publicly disclose: quarterly un audited results & 0.99 & No & Yes \\
\hline 29 & $\begin{array}{l}\text { Does the company publicly disclose: Half yearly Balance Sheet and Profit and Loss } \\
\text { Accounts }\end{array}$ & 0.87 & No & Yes \\
\hline 30 & Does the company publicly disclose: Audited annual Balance Sheet & 0.97 & Yes & Yes \\
\hline 31 & Does the company publicly disclose: Annual Directors' Report & 0.82 & Yes & No \\
\hline 32 & Does the company publicly disclose: Corporate Governance Statement & 0.82 & Yes & No \\
\hline 33 & Does the company publicly disclose: Ownership Structure & 1.00 & Yes & Yes \\
\hline 34 & Does the company publicly disclose: Directors' Shareholding & 0.83 & Yes & No \\
\hline 35 & Does the company publicly disclose: Senior Management Structure & 0.85 & No & Yes \\
\hline 36 & Does the company publicly disclose: Directors' Remuneration & 0.82 & No & Yes \\
\hline 37 & Does the company publicly disclose: Details of Investment & 0.82 & No & Yes \\
\hline 38 & Does the company publicly disclose: Basis of estimates used in financial reporting & 0.82 & Yes & No \\
\hline 39 & Does the company publicly disclose: Depreciation policy & 0.82 & Yes & Yes \\
\hline 40 & Does the company publicly disclose: Tax policy & 0.83 & Yes & Yes \\
\hline
\end{tabular}




\subsection{Correlation Analysis}

The Spearman's correlation matrix for the dependent variable and the independent variables are presented in Table 6.

The correlation matrix shows the correlation between CGI and company size is positively correlated at the $1 \%$ significance level. Furthermore, the correlation between CGI and type of industry suggests that the CGI is positively correlated related to the Bank variable and, on the contrary, negatively related to non-banking financial institutions (NBFI), and in both cases the correlation is significant at the $1 \%$ significance level.

Table 6 also suggests that the correlation between CGI and type of auditor (not affiliated with Big4 auditor) is significantly negative (at the $5 \%$ significance level). Other than these variables, the correlation coefficients between CGI and the other explanatory variables (age, profitability, type of company) are statistically insignificant.

Multicollinearity between explanatory variables needs to be tested before using the regression model, to ensure that the regression model is free from bias. Collinearity is considered as a problem if the variance inflation factor (VIF) value exceeds 10 (Field, 2009, Jackling and Johl, 2009, Mutawaa and Hewaidy, 2010). The correlation coefficient values in Table 6 indicate that there might be some risk between some variables. However, the VIF values in Table 6 (the last row) give assurance that the regression model is free from the risk of bias because all the VIF values are less than 10 for all of the independent variables. Hence it provides strong evidence that multicollinearity is not a problem for the regression model.

Table 6. Correlation Coefficients for Dependent and Independent Variables in the Regression Model

\begin{tabular}{|c|c|c|c|c|c|c|c|c|c|}
\hline & $\begin{array}{c}\text { Compliance } \\
\text { index }\end{array}$ & Log Age & $\log R O A$ & Log Size & $\begin{array}{c}\text { NFI vs } \\
\text { Bank_} \\
\text { dummy }\end{array}$ & $\begin{array}{l}\text { NFI vs } \\
\text { NBFI_ } \\
\text { dummy }\end{array}$ & $\begin{array}{l}\text { Local vs } \\
\text { MNC_- } \\
\text { dummy }\end{array}$ & $\begin{array}{l}\text { Local Vs JV } \\
\text { and } \\
\text { Franchaise_ } \\
\text { dummy }\end{array}$ & $\begin{array}{c}\text { Auditor } \\
\text { affiliated vs } \\
\text { not affiliated } \\
\text { with Big 4_- } \\
\text { dummy }\end{array}$ \\
\hline \multicolumn{10}{|l|}{ Compliance index } \\
\hline Log Age & 0.021 & 1 & & & & & & & \\
\hline Log ROA & -0.077 & $.406 * *$ & 1 & & & & & & \\
\hline Log Size & $.501 * *$ & -0.136 & $-.415^{* *}$ & 1 & & & & & \\
\hline NFI vs Bank_dummy & $.358 * *$ & $-.303 *$ & $-.570^{* *}$ & $.607 * *$ & 1 & & & & \\
\hline NFI vs NBFI_dummy & $-.409 * *$ & $.372 * *$ & $.496 * *$ & $-362 * *$ & $-.585 * *$ & 1 & & & \\
\hline Local vs MNC_dummy & 0.159 & 0.222 & $.422 * *$ & -0.095 & -0.227 & $.388 * *$ & 1 & & \\
\hline $\begin{array}{l}\text { Local vs JV and } \\
\text { Franchaise dummy }\end{array}$ & 0.042 & -0.094 & 0.154 & -0.183 & -0.096 & 0.163 & -0.069 & 1 & \\
\hline $\begin{array}{l}\text { Auditor affiliated vs not } \\
\text { affiliated with Big 4_dummy }\end{array}$ & $-.289 *$ & $.279 *$ & 0.176 & $-.329 * *$ & $-321 * *$ & 0.153 & $-341 * *$ & 0.163 & \\
\hline VIF & & 1.397 & 1.590 & 1.691 & 2.354 & 1.846 & 1.736 & 1.122 & 1.681 \\
\hline
\end{tabular}

**. Correlation is significant at the 0.01 level (2-tailed); *. Correlation is significant at the 0.05 level (2-tailed).

Here,

CGI $=$ Corporate Governance Index; Log_age $=$ Logarithm of the age of the Company; Log ROA = Logarithm of return on asset; Log_Size= Logarithm of total asset; NFI VS Bank_dummy = Banking industry, used as a dummy on the basis of Non Financial Institutions(NFI); NFI vs NBFI = Non-Banking Financial Institutions, used as a dummy on the basis of NFI; Local vs MNC= Multinational companies, used as a dummy on the basis of local companies; Local vs JV and Franchise $=$ Joint venture and Franchise companies, used as a dummy on the basis of local companies; Aud= Companies not audited by firms other than the one affiliated with Big 4 audit firms, used as a dummy variable on the basis of companies which are audited by Big 4 affiliated audit firms.

\subsection{Regression Analysis}

Regression analysis was run using ordinary least squares (OLS) estimates and the results are reported in Table 7. The overall estimation indicates that among the six control variables, four (age, size, industry type (only NBFI compare to NFI) and type of company) have a statistically significant effect on the extent to which companies are complying with the Code.

Panel A of Table 7 indicates the explanatory power of the OLS model. As suggested by the adjusted $\mathrm{R}^{2}$, the explanatory power of the regression model of the study is $46.9 \%(\mathrm{p}<.001)$. The $\mathrm{R}^{2}$ is 0.530 , indicating that the 
model is capable of explaining a $53 \%$ variability in the level of compliance of the sample companies. However the difference between $\mathrm{R}^{2}$ and the adjusted $\mathrm{R}^{2}$ is small, about $6 \%(0.530-0.469=0.061)$. This shrinkage means that if the model were derived from the population rather than a sample it would account for approximately $6 \%$ less variance in the level of compliance score of companies. The Durbin Watson (D-W) test provided assurance about the lack of multicollinearity among the independent variables. As a very conservative rule of thumb, if the value is less than 1 or greater than 3 there is cause for concern (Bowerman and O'Connel, 1990, Field, 2009), however in this study the value is well above that risk level at 1.881, so the variables are not related.

Table 7. Multivariate Analysis

\section{Panel A: Regression Analysis}

\begin{tabular}{lr} 
Coefficient of multiple regression & 0.728 \\
Coefficient of determination $\left(\mathrm{R}^{2}\right)$ & 0.530 \\
Adjusted $\mathrm{R}^{2}$ & 0.469 \\
Durbin-Watson & 1.881 \\
\hline Standard error & 6.677 \\
\hline
\end{tabular}

Panel B: Analysis of Variance

\begin{tabular}{lccccc}
\hline & $\begin{array}{c}\text { Sum of } \\
\text { Squares }\end{array}$ & df & $\begin{array}{c}\text { Mean } \\
\text { Square }\end{array}$ & F & Sig. \\
\hline Regression & 3115.858 & 8 & 389.482 & 8.734 & 0.000 \\
Residual & 2764.734 & 62 & 44.592 & & \\
\hline
\end{tabular}

Panel C: Variables in the equation

\begin{tabular}{|c|c|c|c|c|c|c|c|c|}
\hline & \multicolumn{2}{|c|}{$\begin{array}{l}\text { Unstandardized } \\
\text { Coefficients }\end{array}$} & \multirow{2}{*}{$\begin{array}{c}\begin{array}{c}\text { Standardized } \\
\text { Coefficients }\end{array} \\
\text { Beta }\end{array}$} & \multirow{2}{*}{$t$} & \multirow{2}{*}{ Sig. } & \multicolumn{2}{|c|}{$\begin{array}{c}\text { Collinearity } \\
\text { Statistics }\end{array}$} \\
\hline & & B & Std. Error & & & & $\begin{array}{c}\text { Toleranc } \\
\mathrm{e}\end{array}$ & VIF \\
\hline & (Constant) & 1.691 & 14.469 & & 0.117 & 0.907 & & \\
\hline & Log Age & 4.809 & 1.578 & 0.314 & 3.048 & 0.003 & 0.716 & 1.397 \\
\hline & Log ROA & 0.039 & 1.946 & 0.002 & 0.02 & 0.984 & 0.629 & 1.59 \\
\hline & Log Size & 2.461 & 0.593 & 0.47 & 4.152 & 0.000 & 0.591 & 1.691 \\
\hline \multirow{2}{*}{ Type of Industry } & $\begin{array}{r}\text { NFI vs } \\
\text { Bank_Dummy } \\
\text { Variable }\end{array}$ & -2.653 & 2.849 & -0.124 & -0.931 & 0.355 & 0.425 & 2.354 \\
\hline & $\begin{array}{r}\text { NFI vs } \\
\text { NBFI_Dummy } \\
\text { Variable } \\
\end{array}$ & -9.789 & 2.155 & -0.537 & -4.542 & 0.000 & 0.542 & 1.846 \\
\hline \multirow[b]{2}{*}{ Type of Company } & $\begin{array}{r}\text { Local vs } \\
\text { MNC_dummy }\end{array}$ & 8.24 & 3.002 & 0.315 & 2.745 & 0.008 & 0.576 & 1.736 \\
\hline & $\begin{array}{l}\text { Local Vs JV and } \\
\text { Franchaise_dumm }\end{array}$ & 14.496 & 5.074 & 0.264 & 2.857 & 0.006 & 0.891 & 1.122 \\
\hline \multicolumn{2}{|c|}{$\begin{array}{r}\text { Auditor affiliated vs not affiliated with Big } \\
4 \text { dummv }\end{array}$} & -1.022 & 2.057 & -0.056 & -0.497 & 0.621 & 0.595 & 1.681 \\
\hline
\end{tabular}

The significance of $\mathrm{R}^{2}$ can be further tested using an F-ratio (Field, 2009). Panel B of Table 7 contains the analysis of variance (ANOVA) which tests whether the model is significantly better at predicting the outcome variable than using the mean. The $\mathrm{F}$ statistic $(\mathrm{F}=8.734)$ of this table indicates that the model employed to explain the variation in the level of compliance is significant at the conventional $(p<0.001)$ level, and better at predicting the outcome than simply using the average (mean). Hence we can be confident that the results of this study did not occur by chance.

However, as indicated by the result of Panel $\mathrm{C}$ of Table 7, some variables are more significant in explaining the level of compliance. The following section discusses the findings relating to these variables in detail. 


\subsubsection{Age of the Companies}

Company age denoted by 'log Age' is found to be positively correlated related with the CGI. The findings indicate that if other things remain the same then with a one year increase in the age of the company, the level of compliance increases by 4.809 units $(\mathrm{p}<0.05)$. The findings thus support hypothesis 2 that the level of compliance with the Code provision is significantly and positively correlated with the age of company.

This finding is different to that of Akhtaruddin (2005) who also studied Bangladeshi companies; one possible explanation is that at the time when Akhtaruddin collected his data, it was just the initial year(s) of the implementation of the mandatory provisions he considered, hence he himself mentioned that this may not be a good enough time to understand the impact of the age on compliance level. Whereas using the recent data, the findings of the present study report that there is now a positive correlation between the two variables and that the older companies are complying more than the younger ones. On the other hand, Owusu-Ansah (1998) also has similar findings, i.e. a positive association between age and compliance in Zimbabwe.

\subsubsection{Profitability}

Our findings in relation to profitability and compliance level do not support hypothesis 3 that companies with higher profitability, measured by the ROA, are expected to comply more than the companies with lower profitability. This finding is not consistent with that of Akhtaruddin (2005) who found that in Bangladesh companies with higher profitability are disclosing more. A possible explanation for this might be because Akhtaruddin measured the mandatory provisions regarding disclosure whereas this study deals with much wider areas covered by the voluntary provisions. Nonetheless, the finding of 'no association' between the level of compliance and profitability is consistent with studies such as Wallace et al. (1994) for a sample of Spanish companies, and a recent study by Mutawaa and Hewaidy (2010) who reported that there is no significant association between the level of compliance and profitability of Kuwaiti companies.

\subsubsection{Company Size}

The regression model supports hypothesis 4 that company size measured by total assets is positively correlated with the level of compliance with the Code provisions. The findings indicate that if other things remain the same then with 1 BDT (Bangladeshi Taka) increase in the total assets of the company, the level of compliance increases by $2.461(\mathrm{p}<0.01)$.

Thus the findings are consistent with the studies on Bangladesh including Akhtaruddin (2005) where disclosure provision was measured against mandatory provisions and Habib-Uz-Zaman (2010) who measured compliance relating to CSR reporting information of Bangladeshi listed commercial banks. The findings are also consistent with many other studies on developed and developing countries (Ahmed and Nicholls, 1994, Hossain, 2008, Wallace et al., 1994)

\subsubsection{Industry Type}

Table 7 (Panel C) indicates that the type of industry is statistically significant only in the case of NBFIs. The findings indicate that all other things being equal, the compliance score will be less by 9.78 points $(\mathrm{p}<0.01)$ than would have been the case for NFIs. Overall except for the NBFIs, the industry classification has a negligible effect on the level of compliance of the sample companies.

Similar findings have also been reported by some other studies (Akhtaruddin, 2005, Inchausti, 1997, Owusu-Ansah, 1998), on the other hand the findings also sharply contrast with some others, for instance, Mutawaa and Hewaidy (2010) report that the investment companies which fall under the NBFI of Kuwait, are positively associated with the level of compliance with IAS-required disclosures.

\subsubsection{Type of the Companies}

It was hypothesized that the type of company will be significantly associated with the level of compliance with the Code, where companies controlled by foreign companies (MNCs) or joint venture/franchise companies would be subject to a certain level of influence resulting in them having better governance standards than local companies. Panel $\mathrm{C}$ of Table 7 supports hypothesis 6 and suggests that in both the cases the local companies are complying less with the Code as the findings indicate that the compliance score for MNCs will be more (by 8.24 points) than would be the case for local companies, whilst for J/V and Franchise the level of compliance score increases by 14.496 when compared against the compliance score of local companies.

This finding can be interpreted as the foreign owned companies being controlled by their parent companies which are in most cases exposed to the international market and are required to comply with international standards of corporate governance. 


\subsubsection{Type of Auditors}

The findings do not support hypothesis 7 that the level of compliance will vary by the type of auditor used by the companies. Although the findings suggest that the compliance score decreases 1.02 points when the auditors are not affiliated with any one of the Big4 audit firms, it is statistically insignificant. Hence it cannot be claimed that the Bangladeshi companies audited by the audit firms affiliated with one of the Big4 audit firms have better compliance than those companies audited by other types of audit firms. Similar findings are reported in a recent study (Kabir et al., 2011) which examined the association between Big 4 affiliated auditors and accruals quality in Bangladesh and found no positive impact. They (Kabir et al., 2011) believe that low demand for quality audit and a weak monitoring system are the reasons why the Big 4 audit firms are not able to impact on the accrual quality of their clients. However this finding is not unique for Bangladesh, as other studies (Mutawaa and Hewaidy, 2010, Wallace et al., 1994) also reported the same.

Overall the findings of the regression model suggest that from amongst the six variables -age, size, industry type (but only NBFI compare to NFI) and type of company account for the unique variance in the outcome variable CGI. The other two predictor variables are found to have no statistically significant effect on the level of compliance with the Code.

\section{Summary and Conclusions}

This study aims to identify the extent to which companies are complying with the Code of Corporate Governance for Bangladesh. Moreover, it identifies the provisions that are the most and the least complied with in the Code, and also examines the association between six company attributes and the compliance level. We employ a survey methodology, with a questionnaire being sent to all 229 companies listed on the Dhaka Stock Exchange, and receive 71 responses.

Based on the Code, a corporate governance index (CGI) was developed. The CGI includes 79 provisions of the Code which were divided into three sub-indices - board issues, shareholder issues, and issues related to financial reporting, auditing, and non-financial disclosure.

With regard to our first research objective, which sought to understand the overall level of compliance with the Code amongst the listed companies of Bangladesh, the findings indicate that the overall level of compliance is $67 \%$, indicating a moderate/intermediate level of compliance.

Having ascertained the overall compliance level, we also sought to identify the most and least complied with provisions of the Code. In this regard the findings suggest that compliance is comparatively higher with the provisions related to the financial reporting system, and on the contrary is lower for the board related provisions; and also that the FIs are more compliant than the NFIs. The possible reason for non-compliance on board related issues could be as a result of the lack of infrastructure and ambiguous provisions. For instance, if the board is comprised of family members then the board might be skeptical about the provisions relating to the board members or even the chairman's performance being evaluated and disclosed. However, the overall analysis indicates that in Bangladesh the decision of compliance is most likely to be influenced by the regulatory aspects.

The second research objective was to examine if the level of compliance varies depending on different company attributes. The result of the multivariate analysis suggested that age, size and industry type (in the case of NBFI) and type of company have a statistically positive correlation with the level of compliance with the Code provisions.

Like all studies, ours is not without its limitations. One such limitation is that we measure compliance in terms of corporate governance disclosures. However, considering the sensitivity of corporate governance research, especially in countries like Bangladesh where companies have started their corporate governance reform relatively recently, it is unlikely that companies would allow access to researchers to measure their company's corporate governance practices in depth or by direct observation. Perhaps that is the reason why almost all of the previous research studies on measuring compliance (Ahmed, 2006, Akkermans et al., 2007, Basu and Dimitrov, 2010, Henry, 2008, Mutawaa and Hewaidy, 2010) have the same limitation of measuring compliance by corporate governance disclosures.

Furthermore, future research could look at the trend of compliance over a number of years, and might also consider the impact of other control variables including leverage, liquidity, and culture.

Nonetheless, despite the limitations, the findings of our study have their own merits. This study is the first attempt to bring the evidence from Bangladesh into the large pool of literature by measuring compliance against the voluntary Code of Corporate Governance. The findings can be used as a guideline to develop policies for better implementation of good governance standards. Moreover the findings related to areas of non-compliance 
are expected to help the code formulators, regulators and also companies to understand why and where companies are falling behind in ensuring compliance.

\section{References}

Aboagye, A. Q., \& Otieku, J. (2010). Are Ghanaian MFIs' performance associated with corporate governance? Corporate Governance: An International Review, 10(3), 307-320. https://doi.org/10.1108/14720701011051938

Ahmed, H. (2006). Extent of mandatory compliance in the corporate annual reports of Indian companies - an empirical study. Decision, 33(1), 89-121.

Ahmed, H. (2014). Islamic banking and shari'ah compliance: A product development perspective. Journal of Islamic Finance, 3(2), 15-29. https://doi.org/10.12816/0025102

Ahmed, K., \& Nicholls, D. (1994). The impact of non-financial company characteristics on mandatory disclosure compliance in LDCs: the case of Bangladesh. International Journal of Accounting, 29, 62-77.

Ahmed, M. U., \& Yusuf, M. A. (2005). Corporate governance: Bangladesh perspective. The Cost and Management, 33(6), 18-26.

Akhtaruddin, M. (2005). Corporate mandatory disclosure practices in Bangladesh. The International Journal of Accounting, 40, 399-422. https://doi.org/10.1016/j.intacc.2005.09.007

Akkermans, D., Ees, H. V., \& Hermes, N. et al. (2007). Corporate governance in the Netherlands: An overview of the application of the Tabakslat Code in 2004. Corporate Governance: An International Review, 15(6), 1106-1118. https://doi.org/10.1111/j.1467-8683.2007.00634.x

Alabdullah, T. T., Yahya, S., \& Ramayah, T. (2014). Corporate governance mechanisms and Jordanian companies' financial performance. Asian Social Science, 10(22), 247-262

Alabdullah, T. T. Y., Yahya, S., \& Ramayah, T. (2014). Corporate governance development: New or old concept. European Journal of Business and Management, 6(7), 312-315.

Al-Najjar, B. (2010). Corporate governance and institutional ownership: Evidence from Jordan. Corporate Governance, 10(2), 176-190. https://doi.org/10.1108/14720701011035693

Al-Najjar, B. (2013) The Financial determinants of corporate cash holdings: Evidence from some emerging markets. International Business Review, 22(1), 77-88. https://doi.org/10.1016/j.ibusrev.2012.02.004

Al-Qaisi, K. (2013). The effect of the financial crisis on the Jordanian industrial sector. International Journal of Finance \& Banking Studies, 2(1), 43-47.

Alves, C., \& Mendes, V. (2004) Corporate governance policy and company performance: The Portuguese case. Corporate Governance : An International Review, 12(3), 290-301. https://doi.org/10.1111/j.1467-8683.2004.00370.x

Apostolides, N. (2010). Exercising corporate governance at the annual general meeting. Corporate Governance: An International Review, 10(2), 140-149. https://doi.org/10.1108/14720701011035666

Armstrong, C. S., Bloutin, J. L., Jagolinzer, A. D., \& Larcker, D. F. (2015). Corporate governance, incentives, and tax avoidance. Journal of Accounting and Economics, 60, 1-17. https://doi.org/10.1016/j.jacceco.2015.02.003

Armstrong, C., \& Vashishtha, R., (2012). Executive stock options, differential risk-taking incentives, and firm value. Journal of Financial Economics, 104, 70-88. https://doi.org/10.1016/j.jfineco.2011.11.005

Armstrong, C., Larcker, D. F., Ormazabal, G., Taylor, D. J. (2013). The relation between equity incentives and misreporting: The role of risk-taking incentives. Journal of Financial Economics, 109, 327-350. https://doi.org/10.1016/j.jfineco.2013.02.019

Arun, T. G., \& Turner, J. D. (2004). Corporate governance of banks in developing economies: concepts and issues. Corporate Governance: An International Review, 12, 371-377. https://doi.org/10.1111/j.1467-8683.2004.00378.x

Azmat, F., \& Coghill, K. (2010) Good governance and market-based reforms: A study of Bangladesh. International Review of Administrative Sciences, 71, 625-638. https://doi.org/10.1177/0020852305059602

Basu, N., \& Dimitrov, O. (2010). Sarbanes-Oxley, governance, performance, and valuation. Journal of Financial Regulation and Compliance, 18(1), 32-45. https://doi.org/10.1108/13581981011019615 
Bauwhede, H. V. (2009). On the relation between corporate governance complaince and operating performance. Accounting and Business Research, 39(5), 497-513. https://doi.org/10.1080/00014788.2009.9663380

Bebenroth, R. (2005) German corporate governance code and most commonly unaccepted recommendations: Introduction and some explanation. Corporate Ownership and Control, 3(2), 10-14.

BEI (2004). Code of Corporate Governance for Bangladesh. Dhaka, Bangladesh Enterprise Institute.

Belal, A. R. (1999). Corporate social reporting in Bangladesh. Social and Environmental Accounting, 19(1), 8-12. https://doi.org/10.1080/0969160X.1999.9651601

Belal, A. R. (2001). A study of corporate social disclosures in Bangladesh. Managerial Auditing Journal, 16(5), 274-289. https://doi.org/10.1108/02686900110392922

Belal, A. R. (2002). Stakeholder accountability or stakeholder management: A review of UK firms' social and ethical accounting, auditing and reporting (SEAAR). Corporate Social Responsibility and Environmental Management, 9(1), 8-25. https://doi.org/10.1002/csr.5

Belal, A. R., \& Owen, D. L. (2007). The views of corporate managers on the current state of and future prospects for, social reporting in Bangladesh: An engagement based study. Accounting, Auditing \& Accountability Journal, 20(3), 472-494. https://doi.org/10.1108/09513570710748599

Bowerman, B. L., \& O'Connel, R. T. (1990). Linear statistical models: An applied approach, 2nd.CA: Duxbury: Belmont.

Brenman, N., \& McCafferty, J. (1997). Corporate governance practices in Irish companies. Irish Business and Administrative Research, 18, 116-135.

Campbell, K., Jerzemowska, M., \& Najman, K. (2009). Corporate governance challenges in Poland: Evidence from "comply or explain" disclosures. Corporate Governance: An International Review, 9(5), 623-634. https://doi.org/10.1108/14720700910998184

Chahine, S., \& Safieddine, A. (2011). Is Corporate Governance Different for the Lebanese Banking System? Journal of Management and Governance, 15(2), 207-226. https://doi.org/10.1007/s10997-009-9096-7

Chen, C. H., \& Al-Najjar, B. (2012).The determinants of board size and independence: Evidence from China. International Business Review, 21(5), 831-846. https://doi.org/10.1016/j.ibusrev.2011.09.008

Claessens, S., \& Yurtoglu, B. B. (2013) Corporate governance in emerging markets: A survey. Emerging Markets Review, 15, 1-33. https://doi.org/10.1016/j.ememar.2012.03.002

Conyon, M., \& Mallin, C. A. (1997). A review of compliance with Cadbury. Journal of General Management, 22, 24-37. https://doi.org/10.1177/030630709702200303

Conyon, M., Mallin, C., \& Sadler, G. (2002). The disclosure of directors' share option information in UK companies. Applied Financial Economics, 12, 95-103. https://doi.org/10.1080/09603100110088076

Cooke, T. E. (1989). Disclosure in the corporate annual reports of Swedish companies. Accounting and Business Research, 19(74), 113-124. https://doi.org/10.1080/00014788.1989.9728841

Dahya, J., McConnel, J. J., \& Travlos, N. G. (2002). The Cadbury committee, corporate performance and top management turnover. Journal of Finance, 57, 461-483. https://doi.org/10.1111/1540-6261.00428

Dartey-Baah, K., \& Amponsah-Tawiah, K. (2011). Exploring the limits of western corporate social responsibility theories in Africa. International Journal of Business and Social Science, 2(18), 126-137.

Dedman, E. (2002). The Cadbury committee recommendations on corporate governance: A review of compliance and performance impacts. International Journal of Management Reviews, 4(4), 335-352. https://doi.org/10.1111/1468-2370.00091

Del Brio, E. B., Maia-Ramires, E., \& Perote, J. (2006) Corporate governance mechanisms and their impact on firm value. Corporate Ownership and Control, 4, 25-36. https://doi.org/10.22495/cocv4ilp2

Doble, M. (1997). The impact of Cadbury Code on selection of directors and board composition in UK newly-quoted companies, 1990-1994. Corporate Governance: An International Review, 5(4), 214-223. https://doi.org/10.1111/1467-8683.00063

Drobetz, W., Schillhofer, A., \& Zimmermann, H. (2004). Corporate governance and expected stock returns: Evidence from Germany European financial management, 10, 267-293.

Ferdous, C. S. (2013). Compliance with Codes of Corporate Governance in developing economies: The case of 
Bangladesh. (Doctoral Thesis. University of Birmingham). Available from etheses.bham.ac.uk

Ferdous, C. S., Mallin, C., \& Ow-Yong, K. (2014). Corporate governance in Bangladesh: A comparison with other emerging market countries, in corporate governance in emerging markets. Theories practices and cases. Springer. France.

Fernández-Rodríguez, E., Gómez-Ansón, S., \& Cuervo-García, Á. (2004). The stock market reaction to the introduction of best practices codes by Spanish firms. Corporate Governance : An International Review, 12(1), 29. https://doi.org/10.1111/j.1467-8683.2004.00341.x

Field, A. (2009). Discovering Statistics Using SPSS, $3^{\text {rd }}$, London: Sage.

Garay, U., \& González, M. (2008). Corporate governance and firm Value: The case of Venezuela. Corporate Governance: An International Review, 16(3), 194-209. https://doi.org/10.1111/j.1467-8683.2008.00680.x

Glaum, M., \& Street, D. L. (2003). Compliance with the disclosure requirements of Germany's new market: IAS versus US GAAP. Journal of International Financial Management Accounting, 14 (1), 64-100. https://doi.org/10.1111/1467-646X.00090

Gompers, P., Ishii, J., \& Metrick, A. (2003). Corporate governance and equity prices. Quartrely Journal of of Economics, 118(1), 107-155. https://doi.org/10.1162/00335530360535162

Green, C. J., Murinde, V., \& Suppakitjarak, J. (2003). Corporate financial structures in India. South Asia Economic Journal, 4(2), 245-273. https://doi.org/10.1177/139156140300400205

Habib-Uz-Zaman, K. (2010). The effect of corporate governance elements on corporate social responsibility reporting empirical evidence from private commercial banks of Bangladesh. International Journal of Law and Management, 52(2), 82-109.

Hasan, M. S., Hossain, S. Z., \& Rashidah, A. R. (2014). Corporate governance and corporate accruals: The situation in Bangladesh. The International Journal of Finance, 9, 90-111

Henry, D. (2008). Corporate governance structure and the valuation of Australian firms: Is there value in ticking the boxes? Journal of Business Finance \& Accounting, 35(7/8), 912. https://doi.org/10.1111/j.1468-5957.2008.02100.x

Hossain, M. (2008). Financial reporting and corporate governance disclosures on Indian banks: An empirical analysis. (Doctoral Thesis, University of Liverpool).

Ibrahim, A. A. (2006). Corporate governance in Pakistan: Analysis of current challenges and recommendations for future reforms. Washington University Global Studies Law Review, 5, 323-332.

Igor, G., Joerg Richard, W., \& Jochen, Z. (2006). Does compliance with the German Corporate Governance Code have an impact on stock valuation? An empirical analysis. Corporate Governance : An International Review, 14(5), 432. https://doi.org/10.1111/j.1467-8683.2006.00516.x

Imam, O. M., \& Malik, M. (2007). Firm performance and corporate governance through ownership structure: Evidence from Bangladesh stock market. International Review of Business Research Papers, 3(4), 88-110.

Inchausti, B. (1997). The influence of company characteristics and accounting regulation on information disclosed by Spanish firms. European Accounting Review, 6(1), 45-68. https://doi.org/10.1080/096381897336863

Jackling, B., \& Johl, S. (2009). Board Structure and Firm Performance: Evidence from India's Top Companies. Corporate Governance: An International Review, 17(4), 492-509. https://doi.org/10.1111/j.1467-8683.2009.00760.x

Joy, B. H. (2005). The politics of law and legal profession in Bangladesh. The Daily Star. Dhaka.

Kabir, M. H., Sharma, D., \& Islam, M. A., et al. (2011). Big 4 auditor affiliation and accruals quality in Bangladesh. Managerial Auditing Journal, 26(2), 161-181. https://doi.org/10.1108/02686901111095029

Kha, M. G. S. H., Islam, A. K. M. Z., \& Rashid, H. A., et al. (2009). Current status of corporate governance guidelines in Bangladesh: A critical evaluation with legal aspect. Bangladesh Research Publication Journal, 3(3), 971-981.

Klapper, L., \& Love, I. (2004). Corporate governance, investor protection and performance in emerging Markets. Journal of Corporate Finance, 10, 703-728. https://doi.org/10.1016/S0929-1199(03)00046-4

Kota, H. B., \& Tomar, S. (2010) Corporate governance practices in Indian firms. Journal of Management \& 
Organization, 16, 266-279. https://doi.org/10.1017/S1833367200002170

Krambia-Kapardis, M., \& Psaros, J. (2006). The implementation of corporate governance principles in an emerging economy: a critique of the situation in Cyprus. Corporate Governance: An International Review, 14(2), 126-139. https://doi.org/10.1111/j.1467-8683.2006.00492.x

La Porta, R., Silvanes, F. L. D., \& Shleifer, A. et al. (1998). Law and finance. Journal of Political Economy, 106(6), 1113-1155. https://doi.org/10.1086/250042

La Porta, R., Silvanes, F. L. D., \& Shleifer, A., et al. (1997). Legal seterminants of external finance. Journal of Finance, 52(3), 1131-1150. https://doi.org/10.1111/j.1540-6261.1997.tb02727.x

Lang, M., \& Lundholm, R. (1993). Cross-sectional determinants of analysis ratings of corporate disclosure. Journal of Accounting Research, 31, 246-271. https://doi.org/10.2307/2491273

MacAulay, K., Dutta, S., \& Oxner, M. et al. (2009). The impact of a change in corporate governance regulations on firms in Canada. Quarterly Journal of Finance and Accounting, 48(4), 29-52.

MacNeil, I., \& Li, X. (2006). Comply or Explain": Market discipline and non-compliance with the Combined Code Corporate Governance: An International Review, 14, 486-496.

Mallin, C. (2010). Corporate Governance. $3^{\text {rd }}$, Oxford: Oxford University Press.

Mallin, C., \& Ow-Yong, K. (2012.) Factors influencing corporate governance disclosures: Evidence from Alternative Investment Market (AIM) companies in the UK. European Journal of Finance, 18(5-6), 515-533. https://doi.org/10.1080/1351847X.2011.601671

Manosa, R., Murinde, V., \& Green, C. J. (2007). Leverage and business groups: Evidence from Indian firms. Journal of Economics and Business, 59, 443-465. https://doi.org/10.1016/j.jeconbus.2007.04.006

Minichilli, A, Brogi, M., \& Calabrò, A. (2016). Weathering the storm: Family ownership, governance, and performance through the financial and economic crisis. Corporate Governance: An International Review, 24(6), 552-568. https://doi.org/10.1111/corg.12125

Mutawaa, A. A., \& Hewaidy, A. M. (2010). Disclosure level and compliance with IFRSs: An empirical investigation of Kuwaiti companies. The International Business \& Economics Research Journal, 9(5), 33-49. https://doi.org/10.19030/iber.v9i5.566

Myring, M., \& Shortridge, R. T. (2010). Corporate governance and the quality of financial disclosures. The International Business \& Economics Research Journal, 9(6), 103-110. https://doi.org/10.19030/iber.v9i6.589

Ogbuozobe, F. (2009). A consideration of the impact of the companies and Allied Matters Act (1990) and the Insurance Act (2003) on the board of insurance companies in Nigeria - part 2. International Journal of Law and Management, 51(6), 421-456. https://doi.org/10.1108/17542430911005945

Olayiwola, W. K. (2010). Practice and standard of corporate governance in the Nigerian banking industry. International Journal of Economics and Finance, 2(4), 178-189. https://doi.org/10.5539/ijef.v2n4p178

Owusu-Ansah, S. (1998). The impact of corporate attributes on the extent of mandatory disclosure and reporting by listed companies in Zimbabwe. The International Journal of Accounting, 33(5), 605-631. https://doi.org/10.1016/S0020-7063(98)90015-2

Panday, P.K. \& Mollah, M.A.H. (2011). The judicial system of Bangladesh: An overview from historical viewpoint. International Journal of Law and Management, 53(1), 6-31. https://doi.org/10.1108/17542431111111863

Parsa, S., Chong, G., \& Isimoya, E. (2007). Disclosure of governance information by small and medium-sized companies. Corporate Governance (Bradford), 7(5), 635-648. https://doi.org/10.1108/14720700710827211

Pass, C. (2006). The revised Combined Code and corporate governance: An empirical ssurvey of 50 large UK companies. Managerial Law, 48(5), 467-478. https://doi.org/10.1108/03090550610715963

Reverte, C. (2009.) Do better governed firms enjoy a lower cost of equity capital?: Evidence from Spanish firms. Corporate Governance: An International Review, 9(2), 133-145. https://doi.org/10.1108/14720700910946587

Rosen, R. D. V. (2007). Corporate governance in Germany. Journal of Financial Regulation and Compliance, 15(1), 30-41. https://doi.org/10.1108/13581980710726778 
Rossouw, G. J. (2005). Business ethics and corporate governance in Africa. Business and Society, 44, 94-106. https://doi.org/10.1177/0007650305274851

Salman, A. (2009). Bangladesh's economy: Surrounded by deadly threats. International Journal of Social Economics, 36(1/2), 138-181. https://doi.org/10.1108/03068290910921244

Samaha, K., \& Stapleton, P. (2008). Compliance with international Accounting Standards in a national context: Some empirical evidence from the Cairo and Alexandria stock exchanges. Afro-Asian J. Finance and Accounting, 1(1), 40-66. https://doi.org/10.1504/AAJFA.2008.016890

Sarker, A. E. (2011). The political economy of public enterprise privatization: The case of Bangladesh. International Journal of Management, 28(3), 595-611.

Siddiqui, J. (2010). Development of corporate governance regulations: The case of an emerging economy. Journal of Business Ethics, 91, 253-274. https://doi.org/10.1007/s10551-009-0082-4

Siddiqui, J. (2011). The auditing profession in Bangladesh: Turning the tide? Financial Express. Dhaka, Financial Express.

Siddiqui, J., \& Podder, J. (2002). Effectiveness of bank audit in Bangladesh. Managerial Auditing Journal, 17(8), 502-510. https://doi.org/10.1108/02686900210444833

Silveira, A. D. M. D., \& Saito, R. (2009). Corporate governance in Brazil: Landmarks, codes of best practices, and main challenges. The IUP Journal of Corporate Governance, VIII(2), 20-39.

Singh \& Newberry, S. (2008). Corporate governance and International Financial Reporting Standards (IFRS): The case of developing countries. Research in Accounting in Emerging Economies, 8, 483-518. https://doi.org/10.1016/S1479-3563(08)08016-X

Sobhan, A. (2016). Where institutional logics of corporate governance collide: Overstatement of compliance in a developing country, Bangladesh. Corporate Governance: An International Review, 24(6), 599-618. https://doi.org/10.1111/corg.12163

Sobhani, F. A., Amran, A., \& Zainuddin, Y. (2009). Revisiting the practices of corporate social and environmental disclosure in Bangladesh. Corporate Social Responsibility and Environmental Management, 16, 167-183. https://doi.org/10.1002/csr.193

Street, D. L., \& Gray, S. J. (2002). Factors influencing the extent of corporate compliance with International Accounting Standards: Summary of research monograph. Journal of Accounting, Auditing and Taxation, 11, 51-76. https://doi.org/10.1016/S1061-9518(02)00054-X

Tsamenyi, M., Enninful-Adu, E., \& Onumah, J. (2007). Disclosure and corporate governance in developing countries: Evidence from Ghana. Managerial Auditing Journal, 22(3), 319-334. https://doi.org/10.1108/02686900710733170

Uddin, S., \& Choudhury, J. (2008). Rationality, traditionalism and the state of corporate governance mechanisms: Illustrations from a less developed country. Accounting, Auditing \& Accountability Journal, 21(7), 1026-1051. https://doi.org/10.1108/09513570810907465

Uddin, S., \& Hopper, T. (2003). Accounting for privatisation in Bangladesh: Testing world bank claims. Critical Perspectives on Accounting, 14, 739-774. https://doi.org/10.1016/S1045-2354(02)00188-0

Wallace, R. S. O., \& Naser, K. (1995). Firm-specific determinants of the comprehensiveness of mandatory disclosure in the corporate annual reports of firms listed on the stock exchange of Hong Kong. Journal of Accountancy and Public Policy, 14(2), 311-368. https://doi.org/10.1016/0278-4254(95)00042-9

Wallace, R. S. O., Naser, K., \& Mora, A. (1994). The relationship between the comprehensiveness of corporate annual reports and firm characteristics in Spain. Journal of Accounting and Public Policy, 14(4), 311-368. https://doi.org/10.1016/0278-4254(95)00042-9

Wanyama, S., Burton, B., \& Helliar, C. (2009). Frameworks underpinning corporate governance: Evidence on Ugandan perceptions. Corporate Governance: An International Review, 17(2), 159-175. https://doi.org/10.1111/j.1467-8683.2009.00730.x

Weir, C., \& Laing, D. (2000). The performance-government relationship: The effects of Cadbury compliance on UK quoted companies. Journal of Management and Governance, 4, 265-281. https://doi.org/10.1023/A:1009950903720

Werder, A. V., Talaulicar, T., \& Kolat, G. L. (2005). Compliance with the German Corporate Governance Code: 
An empirical analysis of the compliance statements by German listed companies. Corporate Governance: An International Review, 13(2), 178-187. https://doi.org/10.1111/j.1467-8683.2005.00416.X

World Bank. (2009). Report on the Observance of Standards and Codes (ROSC): Corporate governance country assessment, Bangladesh. The World Bank. [online]. Available from: http://www.worldbank.org

\section{Copyrights}

Copyright for this article is retained by the author(s), with first publication rights granted to the journal.

This is an open-access article distributed under the terms and conditions of the Creative Commons Attribution license (http://creativecommons.org/licenses/by/4.0/). 